\title{
INTERPELAÇÕES AO CURRÍCULO INTERCULTURAL - LEI 11.645/2008': o pajé na sala de aula
}

\author{
Josélia Gomes Neves²
}

\begin{abstract}
RESUMO
O objetivo deste escrito foi apresentar uma elaboração referente às ações e possibilidades do trabalho pedagógico nas escolas sobre o tema Pajés Indígenas a Iuz da Lei 1 1.645/2008 e do Parecer 14/2015. É um estudo de caráter qualitativo cuja principal fonte de dados foi a pesquisa documental possibilitada pela coleta e análise de imagens de cadernos escolares e livros didáticos. Os resultados apontam que apesar de diversas formas de destruição do Pajé, esta autoridade ainda resiste nas práticas sociais das aldeias, uma possível identidade de resistência (CASTELLS, 2018). Neste trabalho, contextualizamos a discussão a partir dos Povos Pataxó, Munduruku e Kamaiurá. Em relação às atividades escolares, notamos a veiculação de imagens do Pajé presentes em cadernos, no entanto, de forma pontual e estereotipada, distante das realidades indígenas. Mas, por outro lado, há mudanças em curso sinalizando que é possível trabalhar as culturas indígenas no ambiente escolar. Concluímos que as abordagens atuais do livro didático sobre o tema sugerem possibilidades de iniciativa decolonial que podem fortalecer a concepção de currículo intercultural com a inserção de conhecimentos efetivos sobre as etnias brasileiras.
\end{abstract}

Palavras-chave: Pajés Indígenas. Lei 11.645/2008. Currículo Intercultural.

\section{INTERPELLATIONS TO THE INTERCULTURAL CURRICULUM - LAW 11.645 / 2008: the pajé in the classroom}

\section{ABSTRACT}

The aim of this paper was to present an elaboration referring to the actions and possibilities of pedagogical work in schools on the theme of Indigenous Pajés in the light of Law 11.645 / 2008 and the Report 14/2015. It is a qualitative study whose main source of data was the documentary research made possible by the collection and analysis of images from school notebooks and textbooks. The results show that

\footnotetext{
1 O presente artigo resulta de um recorte da pesquisa intitulada: "Investigações freireanas e decoloniais: o estudo da História e Culturas Indígenas na perspectiva da Lei 11.645/2008 na Amazônia", que se encontra em andamento (2019-2021). Está sendo desenvolvida pela Linha de Pesquisa Antropologia Etnopedagógica e Currículo do Grupo de Pesquisa em Educação na Amazônia (GPEA), da Universidade Federal de Rondônia e não conta com nenhuma fonte de financiamento.

2 Doutora em Educação Escolar. Docente vinculada ao Departamento de Educação Intercultural (DEINTER) da Universidade Federal de Rondônia. Ji-Paraná-RO - Brasil. Líder do Grupo de Pesquisa em Educação na Amazônia (GPEA). Orcid iD: https://orcid.org/00000003-2318-5397. E-mail: joseliagomesneves@gmail.com; joselia.neves@pq.cnpq.br
} 
despite various forms of destruction of the Pajé, this authority still resists in the social practices of the villages, a possible identity of resistance (CASTELLS, 2018). In this work, we contextualize the discussion from the Pataxó, Munduruku and Kamaiurá Peoples. Regarding school activities, we noticed the placement of images of the Pajé present in notebooks, however, in a punctual and stereotyped manner, distant from the indigenous realities. On the other hand, changes are underway signaling that it is possible to work with indigenous cultures in the school environment. We conclude that the current textbook approaches on the subject suggest possibilities of decolonial initiative that can strengthen the concept of intercultural curriculum with the insertion of effective knowledge about Brazilian ethnicities.

Keywords: Indigenous Pajés. Law 11.645 / 2008. Intercultural Curriculum.

\section{INTERPELACIONES AL CURRÍCULO INTERCULTURAL EN BRASIL - LEY 11.645 / 2008: el chamán en el aula}

\section{RESUMEN}

El objetivo de este artículo es estudiarlas acciones y posibilidades del trabajo pedagógico en las escuelas sobre el tema de los pajés indígenas a la luz de la Ley 11.645 / 2008 y la Opinión 14/2015. Desde una perspectiva de investigación cualitativa a través de la recopilación y análisis de imágenes de cuadernos escolares y libros de texto, entre otros, se plantea que que, a pesar de las diversas formas de destrucción del Pajé, esta autoridade se resiste a las prácticas sociales de los pueblos y existeuna posible identidade basada en la resistencia.. En este trabajo se c contextualiza la discusión de los pueblos Pataxó, Munduruku y Kamaiurá como casos de estudio y se explican las actividades escolares donde destacala colocación de imágenes del Pajé presente en cuadernos, de manera puntual y estereotipada, así como distante de las realidades indígenas. Se deduce que existen cambios que indican que es posible trabajar con culturas indígenas más allá del entorno escolar y se encuentra que los enfoques actuales del libro de texto sobre el tema, advierten posibilidades de iniciativa descolonial que pueden fortalecer el concepto de currículo intercultural con la inserción de un conocimiento efectivo sobre las etnias brasileñas.

Palabras clave: Pajés indígenas. Ley 11.645 / 2008. Currículum Intercultural Brasil

\section{INTRODUÇÃO}

As escolas brasileiras comumente desenvolvem ações pontuais relativas à presença indígena no currículo, geralmente em uma data préfixada, o "dia do índio". Este tipo de atividade tem sido alvo de críticas por representar um indígena inexistente e com isso não assegurar consistência pedagógica que permita a elaboração de aprendizagens culturais mais consistentes sob o ponto de vista dos povos originários. Em função disso e do próprio incômodo das principais interessadas - as sociedades indígenas, por 
meio de seus representantes do movimento indígena, indigenista e através de seus intelectuais têm problematizado a imagem veiculada na escola, por não corresponder nem ao passado e nem tampouco à contemporaneidade e variedade dos povos.

Nesta direção, a publicação da Lei 11.645/2008 e posteriormente do Parecer 14/2015, dispositivos normativos que estabeleceram a obrigatoriedade do estudo das sociedades indígenas no currículo têm produzido importantes impactos na educação brasileira. Dentre as mobilizações existentes citamos o Projeto de Pesquisa, "Investigações freireanas e decoloniais: o estudo da História e Culturas Indígenas na perspectiva da Lei 1 1645/2008 na Amazônia".

Um de seus objetivos é refletir a atuação dos Pajés a partir de diferentes povos indígenas e suas repercussões na sala de aula. Nesta direção propõe reflexões no intuito de contribuir para aprendizagens interculturais críticas na educação básica. O estudo vem sendo desenvolvido em Ji-Paraná, Rondônia desde julho de 2019 e com previsão de conclusão para julho de 2021.

Esta proposição é caracterizada como uma pesquisa qualitativa, abordagem que "[...], trabalha com o universo dos significados, dos motivos, das aspirações, das crenças, dos valores e das atitudes. Esse conjunto de fenômenos humanos é entendido aqui como parte da realidade social, [...]" (MINAYO, 2002, p. 21-22).

A questão principal que explicitou o interesse desta investigação foi traduzida na seguinte questão: Como a escola de educação básica tem desenvolvido o tema "Pajés Indígenas" na sala de aula tendo por referência a Lei 11.645/2008 e o Parecer 14/2015? A formulação da problemática é uma importante etapa da pesquisa, necessária na medida em que: "[...]. As perguntas são um convite para uma resposta e ajudam a centrar a atenção do pesquisador nos dados necessários para proporcionar tal resposta" (GIL, 2008, p. 38).

Adotamos também a Pesquisa-Ação no âmbito da educação, metodologia orientadora do Projeto de Pesquisa em discussão, por constituir 
um "[...] instrumento de formação e de produção coletiva de conhecimento das/nas práticas pedagógicas, dando relevo aos princípios que estruturam e dão fundamento às finalidades educativas e científicas do processo" (FRANCO, 2012, p. 2). Significa afirmar que esta escrita propõe reflexões teóricas com potencial de viabilização em sala de aula.

Assim, a finalidade deste estudo foi compreender como a escola de educação básica tem desenvolvido o tema "Pajés Indígenas" na sala de aula considerando a legislação referente - Lei 11.645/2008 e o Parecer 14/2015. Estes documentos normativos, a nosso ver podem impulsionar tensionamentos no currículo para além do "dia do índio".

Como um estudo qualitativo, consideramos adequada a pesquisa documental, que: "[...] consiste em todo texto escrito, manuscrito ou impresso, [...], as fontes, primárias ou secundárias, que, por definição, são exploradas - e não criadas - no contexto de um procedimento de pesquisa" (CELLARD, 2008, p. 297). Os documentos utilizados neste trabalho são imagens que foram retiradas de 4 (quatro) cadernos escolares ${ }^{3}$ e 2 (dois) livros didáticos ${ }^{4}$ de estudantes dos anos iniciais do ensino fundamental.

Esperamos que esta investigação possa desafiar e inspirar práticas docentes de modo a mobilizar mecanismos de aprofundamento sobre o trabalho desta autoridade indígena, o Pajé que teima em existir na atualidade. Um exercício intercultural que pode evidenciar um pouco das subjetividades existentes no mundo indígena.

\section{A TEMÁTICA INDÍGENA EM SALA DE AULA: sobre os Pajés indígenas do Brasil}

Dos meus tempos de escola primária, lembro inicialmente que não se conheciam sociedades indígenas: tratava-se de "índios" ou simplesmente "índio". [...], "adoravam" Jaci, Guaraci e Tupã, orientados pelo pajé (praticante de feitiçarias) e por valente cacique [...]. Deixavam-se "iludir" até mesmo por pequenas bugigangas como facas e espelhinhos oferecidos pelos europeus! Isso era o que afirmavam os livros didáticos (CAINELLI, 2010, p. 165-166, grifo nosso).

\footnotetext{
3 Cadernos escolares - Arquivos GPEA (2019).

${ }^{4}$ Charlier (2017); Alvares; Cesar; Nicoleti (2017).
} 
As reflexões da epígrafe suscitam mobilizações. Referem-se a permanência de uma narrativa colonial na escola que reedita representações estereotipadas sobre os Povos Indígenas. Nessa direção, torna-se importante e necessário aprofundar estudos sobre temas relacionados ao universo indígena.

Nesta direção, apontamos como estratégia didático-metodológica para um maior conhecimento sobre as nações indígenas a possibilidade de construir aprendizagens interculturais efetivas, por meio do estudo dos Pajés: "[...] participantes das ações envolvendo a sobrevivência pessoal e coletiva, [...] têm estado direta ou indiretamente relacionados com a maior parte dos movimentos intra e extratribais das populações indígenas no Brasil [...]" (BOTELHO; COSTA, 2006, p. 928). Entendo que o tema Pajés Indígenas, pode representar uma viabilidade de trabalho no ambiente escolar. Em uma linguagem adequada ao nível de compreensão das crianças da educação básica, os estudantes poderão aprender os diversos significados culturais que o assunto exige. Uma proposição na direção da Lei 11.645/2008 referente ao estudo da História e das culturas indígenas:

\begin{abstract}
Art. 26-A. Nos estabelecimentos de ensino fundamental e de ensino médio, públicos e privados, torna-se obrigatório o estudo da história e cultura afro-brasileira e indígena. $\S 1^{\circ} \mathrm{O}$ conteúdo programático a que se refere este artigo incluirá diversos aspectos da história e da cultura que caracterizam a formação da população brasileira, a partir desses dois grupos étnicos, tais como o estudo da história da África e dos africanos, a luta dos negros e dos povos indígenas no Brasil, a cultura negra e indígena brasileira e o negro e o índio na formação da sociedade nacional, resgatando as suas contribuições nas áreas social, econômica e política, pertinentes à história do Brasil [...] (BRASIL, 2008, p.1).
\end{abstract}

Significa um canal de ampliação do estudo da diversidade religiosa situando as espiritualidades indígenas como importantes manifestações deste contexto. Iniciativas como essa podem produzir um efeito relevante sobre os conhecimentos das tradições indígenas, uma vez que já há um reconhecimento de que: "[...] não são poucos os místicos e religiosos que buscam encontrar nos pajés indígenas aquelas explicações últimas sobre o 
cosmos que nossa sociedade deixou de lado [...]" (LOPES DA SILVA; GRUPIONI, 1995, p. 452).

Tenho discutido em vários encontros de formação docente que para trabalhar pedagogicamente as culturas indígenas não é preciso ser antropólogo ou antropóloga, precisamos ser professores, professoras, construir saberes críticos sobre o assunto. É um estudo que como as demais atividades didáticas de qualidade exige tempo para um planejamento adequado por meio de levantamento e sistematização de informações com vistas à materialização de uma situação de aprendizagem com sentidos. Em alguns momentos, diante de questões mais aprofundadas, evidentemente há necessidade de recorrer a leituras especializadas no âmbito antropológico ou linguístico.

Informo que a cada seção aprofundaremos a metodologia que possibilitou a sua elaboração. Em um primeiro momento, no intuito de possibilitar aproximações com o tema, Pajés Indígenas - apresentamos uma breve reflexão a respeito de suas atividades na perspectiva dos Povos Pataxó, Munduruku e Kamaiurá. Posteriormente, demonstramos como algumas escolas desenvolvem atividades pedagógicas que possuam relação com o tema. Na última seção, discutimos perspectivas outras a respeito dos Pajés por meio de publicações didáticas e literárias que sugerem mudanças no ambiente pedagógico, principalmente no que diz respeito às produções autorais indígenas.

\section{SOBRE PAJÉS: perspectivas Pataxó, Munduruku e Kamaiurá}

A cidade do colonizado é um lugar de má fama, povoado por homens de má reputação. Lá eles nascem, pouco importa aonde e como; morrem lá, não importa aonde ou como. [...]. A cidade do colonizado é uma cidade com fome, fome de pão, de carne, de sapatos, de carvão, de luz. A cidade do colonizado é uma vila agachada, uma cidade ajoelhada (FANON, 1968, p. 29).

Esta seção discute em caráter introdutório, o significado, a importância e as atribuições do Pajé entre os Povos Indígenas a partir das etnias, Pataxó (CAMPOS NEVES, 2013; BONFIM, 2017), Kamaiurá (JUNQUEIRA, 2004) e 
Munduruku (SCOPEL; DIAS-SCOPEL; LANGDON, 2015), por meio da pesquisa bibliográfica. Um recurso metodológico que "[...] utiliza fundamentalmente das contribuições dos diversos autores sobre determinado assunto [...]" (GIL, 2008, p. 51). As diferentes visões aqui apresentadas discutem o Pajé, seus poderes, atuação mediadora no campo espiritual (BOTELHO; COSTA, 2006), a desqualificação de seu trabalho como permanente estratégia de aniquilamento colonial (SILVA; SOUZA, 2017). Uma espécie de "cidade do colonizado" que elabora reações traduzidas como "identidade de resistência" (CASTELLS, 2018).

O Pajé constitui uma figura enigmática, misteriosa no imaginário brasileiro. As leituras sugerem que independe de gênero - pode ser masculino ou feminino, embora na maioria dos trabalhos a referência a um perfil masculino. Neste sentido, o Dicionário Michaelis registra a palavra Pajé, como paié de origem tupi que na perspectiva etnológica corresponde a um mediador espiritual:

Entre os povos indígenas da família tupi-guarani, indivíduo responsável pelos rituais mágicos, com atribuições de invocar e controlar os seres espirituais, além de possuir poderes de cura e de fazer profecias; mandachuva; chefe da pajelança; indivíduo com atribuições de benzedeiro e curandeiro5.

Atua na intercessão entre o mundo "real" e o desconhecido, na ausência de outros termos, tendo em vista que talvez não exista essa fronteira. Sua atribuição central é conhecer e antecipar situações do sobrenatural: "[...] homens e mulheres investidos de poderes especiais - [...] voltados para intermediar ações especiais capazes de refrear o medo da dor e da morte, não só no aspecto pessoal, mas também no coletivo [...]" (BOTELHO; COSTA, 2006, p. 928). São pessoas que aos olhos do seu grupo ou sociedade elaboram conhecimentos sobre o além de modo a enfrentar as situações adversas, em determinados contextos contam com a ajuda dos animais, caso dos Kamaiurá do Xingu:

5 Disponível em: http://michaelis.uol.com.br/busca? $r=0 \& f=0 \& t=0 \& p a l a v r a=p a j \% C 3 \% A 9$ Acesso em: 22 dez. 2019. 
[...]. A existência do próprio pajé, enquanto especialista em cura, deve-se à ajuda que os bichos lhe concedem, ensinando-lhe como fumar, como lidar com as doenças e curar. No mais das vezes, sem a ajuda do espírito do animal protetor, é impossível ao pajé acabar com a doença, auxiliar um parto complicado, localizar pessoas extraviadas na mata etc. [...]. (JUNQUEIRA, 2004, p. 292).

Já na perspectiva do Povo Munduruku, estudos apontam que no contexto das alterações culturais no campo da saúde, há atividades desenvolvidas por indígenas mesmo diante da preponderância da atuação médica. É o caso dos Agentes Indígenas de Saúde (AIS) e dos Pajés, estes últimos, ainda são os responsáveis por determinadas situações que dependem exclusivamente de seu trabalho:

[...]. A circulação dos diversos seres entre os mundos terrestre, subterrâneo, subaquático e o centro da floresta compõe fonte de perigo que pode gerar doenças e morte. Apenas o pajé, ou sacaca, tem a habilidade de circular entre esses mundos, afastando ou promovendo parcerias com os espíritos para buscar a cura (SCOPEL; DIAS-SCOPEL; LANGDON, 2015, p. 2561).

$\mathrm{Na}$ atualidade, são significativas as ocorrências que atestam a existência dos Pajés e sua importância como protetor entre diferentes sociedades indígenas. No entanto, é importante ressaltar que desde a chegada dos europeus, o Pajé tem sido uma das autoridades mais combatidas: "[...] Os indígenas brasileiros sofreram muitas opressões ao longo da história, incluindo a proibição das práticas espirituais [...]" (SILVA; SOUZA, 2017, p. 204). Enfraquecer, aterrorizar e desmoralizar seu trabalho foram os verbos que nomearam a brutal e histórica perseguição por parte das religiões hegemônicas e seus alinhamentos aos projetos de poder da época:

O conjunto de interesses, em muitas circunstâncias, mostra os religiosos das várias ordens comportando-se muito mais agressivamente em relação ao poder do pajé, certamente porque além de identificarem o real conflito de competência entre as práticas de curas e fé oferecidas pelo pajé e as preconizadas pelo cristianismo medieval, também era vital ao processo colonial vencer a resistência para manter o território (BOTELHO; COSTA, 2006, p. 932).

Apesar destes embates, os Pajés teimam em existir no século XXI. A necessidade de sobrevivência mobilizou diversos mecanismos de tradução 
(HALL, 2006) aos contextos produzidos. Esses processos de ressignificação cultural permitem reorganizar as mudanças de modo a aprender a lidar com elas e isso repercute em alguns de seus fazeres. Talvez esse movimento de reação política possa ser interpretado como uma identidade de resistência: "[...] criada por atores que se encontram em posições/condições desvalorizadas ou estigmatizadas pela lógica da dominação, construindo, assim, trincheiras de resistência e sobrevivência [...]" (CASTELLS, 2018, p. 56). A identidade de resistência em algumas situações pode agir como reafirmação de pertencimento étnico e territorial. Refiro-me ao caso de Alberto do Espírito Santo Matos, o Pajé Itambé Pataxó e sua luta para permanecer no território ancestral: "[...] um dos líderes dos nativos da região. Pai de oito filhos nasceu no Monte Pascoal e mora há 30 anos em Coroa Vermelha, onde vende artesanato e ervas medicinais"6.

Estudos dão conta que ocorreram "[...] muitas lutas e dificuldades para posse da terra. Alguns dos primeiros moradores indígenas foram Itambé e sua família [...]" (BONFIM, 2017, p. 32). Itambé atua na cura principalmente por meio do uso de garrafadas à base de ervas medicinais com recomendações para diversas enfermidades. Um conjunto de conhecimentos da tradição, pois: "[...] os Pataxó sempre tiveram conhecimentos sobre as plantas e que as utilizavam, e ainda utilizam, para o tratamento de doenças [...]" (CAMPOS NEVES, 2013, p. 9).

Foi possível observar que alguns dos aspectos referentes ao significado de ser Pajé nas etnias Pataxó, Kamaiurá e Munduruku apresentam elementos comuns, mas o ponto forte são as diferenças de cada Povo. Significa afirmar que é importante romper com a visão genérica do Pajé desvinculado de sua comunidade de origem. Sua atuação está profundamente relacionada à cultura a qual pertence além da língua instrumento fundamental nos rituais.

6 ÍNDIOS não festejam a chegada de Cabral Itambé não vê motivos para comemorar os 500 do Brasil. Folha de São Paulo. Junho de 1998, p. 16. Disponível em: https://wwwl.folha.uol.com.br/fsp/turismo/fx08069820.htm 


\title{
A ESCOLA DESENVOLVE ATIVIDADES RELACIONADAS AO TEMA PAJÉS INDÍGENAS?
}

\begin{abstract}
Aceitar e respeitar a diferença é uma dessas virtudes sem o que a escuta não se pode dar. Se discrimino o menino ou menina pobre, a menina ou o menino negro, o menino índio, a menina rica; se discrimino a mulher, a camponesa, a operária, não posso evidentemente escutá-las e se não as escuto, não posso falar com eles, mas a eles de cima para baixo. Sobretudo, me proíbo entendêlos. Se me sinto superior ao diferente, não importa quem seja, recusome escutá-lo ou escutá-la [...] (FREIRE, 2002, p. 76).
\end{abstract}

Esta seção tem a finalidade de analisar as práticas pedagógicas por meio da pesquisa documental no intuito de compreender um pouco do que acontece na sala de aula. Para tanto foi preciso realizar observação sistemática em cadernos escolares de diferentes anos do ensino fundamental I no intuito de localizar pistas referentes ao tema, Pajé Indígena.

Estes registros, embora ainda sejam considerados "[...] documentos, aparentemente sem nenhuma importância, testemunham nossos modos de aprender, ensinar, [...], registrar e preservar e, por isso, interessam a todos que procuram compreender a história e a história da educação [...]" (MIGNOT, 2005, p. 35-36). Eleger os cadernos escolares como documentos necessários à compreensão do que acontece na sala de aula a partir de seus registros, tem sido um exercício que temos desenvolvido há mais de uma década (NEVES, 2009) e não temos encontrado na literatura estas conexões. Dentre as compreensões construídas destacamos o reconhecimento da ampliação da pesquisa documental com a inclusão de materiais didáticos que disponibilizam pistas relevantes sobre o rumo das aprendizagens.

Neste estudo examinamos 23 (vinte e três) cadernos de crianças, estudantes dos anos iniciais I, pertencentes ao acervo do Grupo de Pesquisa. Foi possível observar que em apenas 4 (quatro) deles havia imagens e textos com atividades correspondentes ao tema. Há uma atividade escrita no âmbito do componente curricular de História, intitulada: "Os primeiros habitantes do Brasil" e três registros que são cópias extraídas da internet - o que nos faz pensar no alcance da reprodução destes materiais de fácil 
acesso nas salas de aula do país. As características são as mesmas, tanto os traços dos desenhos - franja, penas e cocar e a palavra em comum, pajé.

A imagem "Narrativas coloniais" refere-se às atividades que foi possível coletar em dois cadernos escolares de estudantes da rede pública do estado de Rondônia. A primeira foi encontrada em um caderno do $5^{\circ}$ ano do ensino fundamental. Trata de um texto que aparenta ter sido produzido de forma espontânea, considerando as escritas com traços de marcas orais: tribus e descubrimento.

Figura 1 - Narrativas coloniais
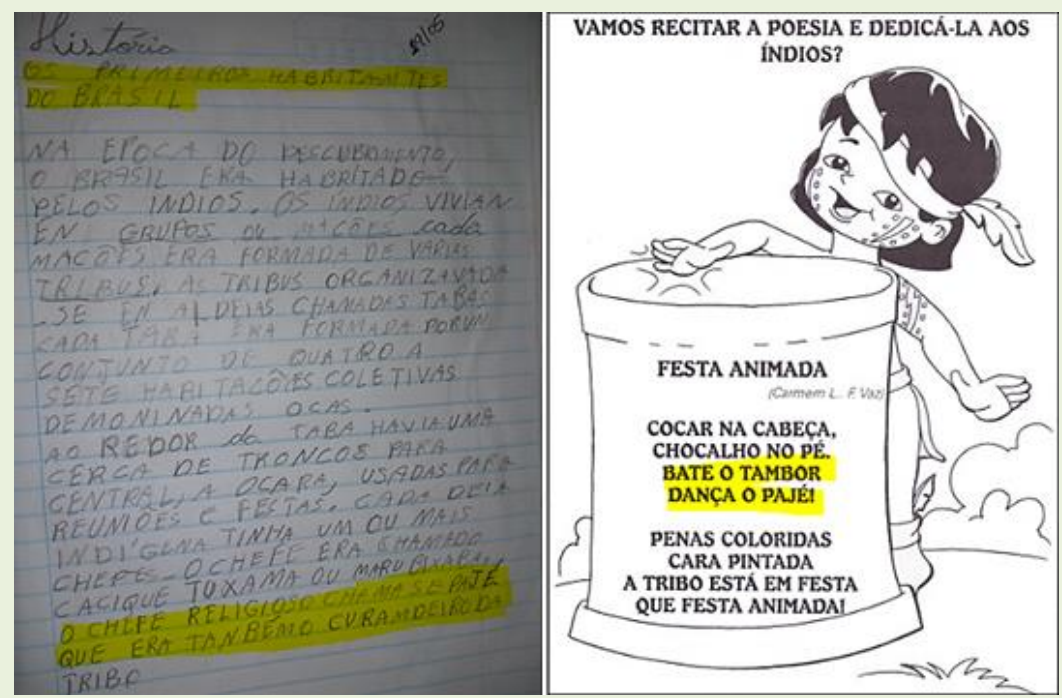

Fonte: Cadernos escolares - Arquivos GPEA (2019).

No entanto, pelas palavras apresentadas índio, tribo, taba, oca, sugere vinculações com explicações anteriores, possivelmente oriundas de livros didáticos. A referência exclusiva dos dados informados no texto diz respeito a costumes de povos da época da chegada europeia, a marcação do colonizador, uma negação da vida indígena anterior. "A costa atlântica, ao longo dos milênios, foi percorrida e ocupada por inumeráveis povos indígenas. Disputando os melhores nichos ecológicos, eles se alojavam, desalojavam e realojavam, incessantemente [...]" (RIBEIRO, 1995, p. 29).

Nestas narrativas prevalece a repetição mecânica que como eco se materializa nas salas de aula do país, dentre outras, que os "índios foram os primeiros habitantes do Brasil". Uma afirmação vazia de sentidos, desprovida 
de significados, que em nada reduz a violência brutal cometida contra os Povos Indígenas por meio de constantes invasões em seus territórios ${ }^{7}$. Em relação às atividades "Vamos recitar a poesia e dedicá-la aos índios?", "Pajé" e "Na tribo eles vivem [...]", são cópias reproduzidas de páginas da internet ${ }^{8}$, localizadas em um caderno de $2^{\circ}$ ano do ensino fundamental.

Figura 2 - Atividades "Dia do Índio"

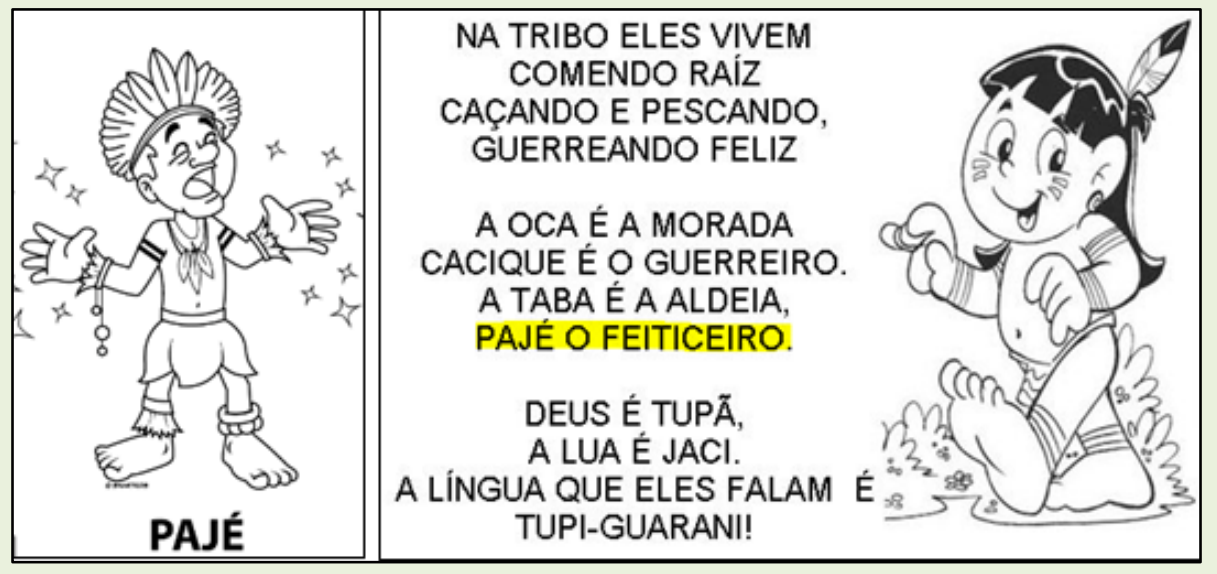

Fonte: Arquivos GPEA (2019).

A imagem, Atividades "Dia do Indio" trata dos dois outros registros que localizamos nos cadernos escolares da região central de Rondônia, $1^{\circ}$ e $3^{\circ}$ ano do ensino fundamental, respectivamente. As duas imagens também foram extraídas da internet, apresentam informações que evidenciam uma "[...] visão e noção de índio genérico, ignorando a diversidade que sempre existiu entre esses povos; [...] generalização de traços culturais de um povo para todos os povos indígenas; [...]" (BRASIL, 2015, p. 6). Outras semelhantes a estas, são comuns nos cadernos da região de Ji-Paraná, em Rondônia, sempre relacionadas à datas comemorativas. Um material cujo acesso tem feito parte da rotina docente, considerando as colagens observadas nos cadernos (FIALHO, 2018).

\footnotetext{
7 Indígenas denunciam aumento de grileiros, ameaças, tiroteios perto de aldeias e diminuição da caça e pesca no território. Disponível em: https://www.socioambiental.org/pt-br/blog/blog-do-monitoramento/centenas-de-invasoresentram-na-terra-indigena-uru-eu-wau-wau-e-preparam-derrubada-da-floresta. Acesso em: 22 dez. 2019.

8 Disponível em: https://www.atividadesedesenhos.com/2012/01/dia-do-indio-atividades-edesenhos-viii.html. Acesso em: 22 dez. 2019.
} 
Como as atividades anteriores foi possivel observar que há poucos registros sobre os povos Indígenas nos cadernos escolares. E nestas escassas anotações permanecem as concepções de um currículo ancorado em datas comemorativas, como o "dia do índio". Assim, podemos afirmar que na região central do estado de Rondônia, há escolas que desenvolvem atividades sobre os Pajés Indígenas. Entretanto, ocorre de forma pontual, caricata e sem um planejamento aprofundado como exige qualquer outra situação didática que pretenda possibilitar aprendizagens significativas. Reiteram estudos anteriores que evidenciaram que a presença indígena no currículo escolar é veiculada em um conteúdo genérico, que nega as dinâmicas sociais históricas e identitárias (NEVES, 2017).

Persiste a mentalidade de que as nações indígenas pertencem exclusivamente ao passado e em uma marcação colonizatória, são lembrados apenas no dia "22 ou 19 de abril". Outro problema nessa visão, é que as diversas etnias reduzem-se a uma única imagem no contexto histórico brasileiro, em uma moldura de suposta pureza identitária e ao mesmo tempo são vistos como figuras excêntricas de uma diferença que vale apenas no plano exótico, em suma, uma recusa às suas existências na contemporaneidade (BRASIL, 2015).

As informações presentes nos cadernos escolares têm explicitado que os conteúdos veiculados em sala de aula, são desatualizados e se caracterizam muito mais pelo desconhecimento das etnias brasileiras - suas línguas - faladas e escritas, a manutenção de suas culturas e os problemas que enfrentam como sociedades minoritárias na atualidade. Neste sentido, a escola presta um desserviço aos Povos Indígenas e a educação ao "[...] veicular preconceitos e discriminações sobre os Povos Indígenas ao invés de produzir mecanismos para a sua superação [...]" (NEVES, 2017, p. 1).

Mas, há indícios da temática indígena crítica que aos poucos ocupa e tensiona o território pedagógico dos livros didáticos e literários, provocando fagulhas de possibilidades interculturais. A intenção é a "[...] valorização da identidade, da história e da cultura dos povos indígenas, [...] de todos os 
grupos étnicos e raciais constituidores da sociedade brasileira [...]" (BRASIL, 2015, p. 8).

\section{NOVAS PERSPECTIVAS PARA O ESTUdO DA TEMÁtICA INDÍGENA NO CURRÍCULO ESCOLAR: tensionamentos ao livro didático?}

[...] [a] História sobre os indígenas modificou-se bastante: novas fontes, em cartórios, igrejas e arquivos nacionais e estrangeiros foram localizadas e catalogadas. Cresceu o interesse dos historiadores por questões que envolvem a família, cotidiano, parentesco, identidades, religiosidade, língua, e representações construídas sobre os indígenas (CAINELLI, 2010, p. 166).

Temos analisado no Grupo de Pesquisa livros didáticos da área de História, Língua Portuguesa, Geografia e Arte dos anos 2010-2018. Nosso olhar para estes materiais leva em conta suas características de suportes veiculadores de interesses sociais e pedagógicos, pois, "[...] estabelecem grande parte das condições materiais para o ensino e a aprendizagem nas salas de aula de muitos países através do mundo [...] são os textos destes livros que [...] definem qual é a cultura legítima a ser transmitida" (APPLE, 1995, p. 82). Nesta direção, compreendemos que os materiais escolares podem disponibilizar importantes elementos a respeito das representações das sociedades indígenas, produzidas pelas perspectivas culturais e linguísticas majoritárias. Mas, como os Povos Indígenas são representados nos livros didáticos analisados no que se refere aos Pajés?

No decorrer deste trabalho observamos importantes publicações referentes à temática indígena e sua relação com os livros didáticos na perspectiva da desconstrução das narrativas coloniais na escola que se aproximam das exigências da Lei 11.645/2008. Destaco os estudos inaugurais de Telles (1987), Grupioni (1995), Lopes da Silva; Grupioni (1995) e os textos atuais de Gobbi (2006), Cavalheiro; Costa (2007), Prints (2014) e Neves (2016).

Embora sejam materiais que anunciem possibilidades de trabalho sobre os Povos Indígenas na escola e que denunciem o esvaziamento do significado da atuação do pajé nos livros didáticos, não discutem de forma específica esta relação. Os termos denúncia e anúncio são elementos 
indissociáveis na perspectiva freireana. São úteis para compreender as representações sobre o pajé neste material, uma vez, que: "[...], não há utopia verdadeira fora da tensão entre a denúncia de um presente tornando-se cada vez mais intolerável e o anúncio de um futuro a ser criado, construído, política, estética e eticamente, por nós, mulheres e homens [...]" (FREIRE, 1997, p. 47).

A pesquisa de natureza documental possibilitou o desenvolvimento deste estudo, pois significa: "[...] uma fonte 'natural' de informação, [...] surge num determinado contexto e fornecem informações sobre esse mesmo contexto" (LUDKE; ANDRÉ, 1986, p. 39). Neste levantamento, em relação ao tema Pajés Indígenas identificamos referências em dois livros didáticos diferentes, são anúncios esperançosos: a primeira imagem referese ao Povo Desana, sociedade indígena do Amazonas com informes sobre sua atuação no meio social e a outra diz respeito a uma narrativa mítica sobre o surgimento do dia e da noite do Povo Kayabi, do Mato Grosso.

Figura 3 - Pajé Desana

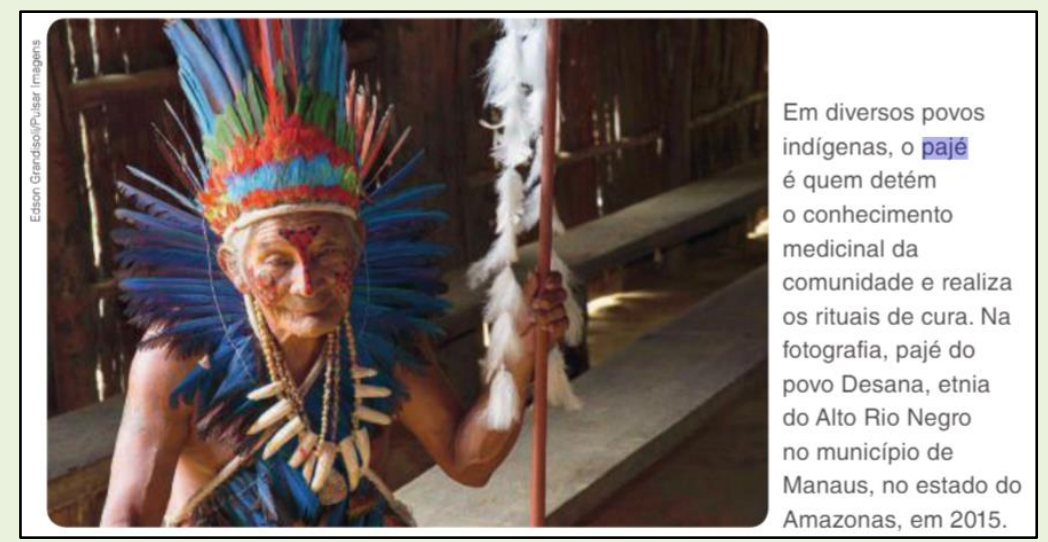

Fonte: Alvares; Cesar; Nicoleti (2017, p. 219).

A atividade foi localizada em um livro do $4^{\circ}$ ano do ensino fundamental sobre o Povo Desana. Discute o conhecimento do Pajé no que se refere às plantas medicinais e processos de cura. O conteúdo reconhece a contribuição da medicina tradicional indígena como importante matéria prima na indústria farmacêutica, confirmando que: "[...] a dívida que a humanidade contraiu com o saber etnobotânico do primitivo habitante das 
Américas está longe de ser resgatada. As principais plantas [...] foram descobertas e domesticadas pelos ameríndios [...]" (RIBEIRO, 1995, p. 199).

Destaca a biodiversidade brasileira e os saberes dos Povos Originários e de certa forma, denuncia as perseguições e reiteradas formas de saques e apropriação destes conhecimentos através da biopirataria. Discussão importante da atualidade indígena que exige "[...] um regime jurídico de proteção aos conhecimentos tradicionais associados à biodiversidade [...], nos últimos anos estes conhecimentos tornaram-se alvos de biopirataria, especialmente por parte de empresas multinacionais" (SANTOS, 2008, p. 10).

Foi possível observar que a atividade proposta aproxima-se das exigências da Lei 11.645/2008 e do Parecer 14/2015, uma vez que de forma interdisciplinar discute a temática indígena. Identifica o povo indígena e sua localização em um tema importante como os saberes do Pajé Desana sobre as plantas medicinais, confirmando que: "[...] o índio não era leigo em história natural. Pelo contrário, sua contribuição à biologia (flora e fauna), à agricultura, bem como à medicina empírica, mal começa a ser avaliada" (RIBEIRO, 2013, p. 3).

Analisamos que a imagem apresenta boa qualidade e representa um Pajé "de verdade". Há indicação de fontes adequadas para o aprofundamento do assunto, elementos que permitem afirmar que é uma proposição didática crítica que aliada a outras ações pode resultar em compreensões mais próximas das realidades indígenas.

Figura 4 - Mito do Dia/Noite do Povo Kayabi

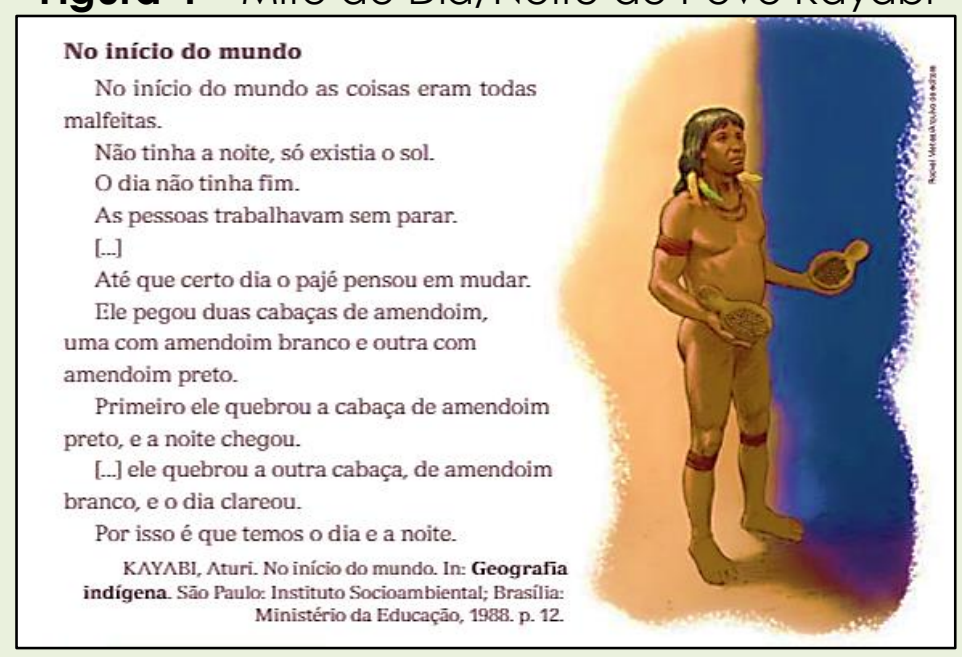

Fonte: Charlier (2017, p. 28). 
A segunda imagem foi localizada em um livro didático de História do $5^{\circ}$ ano do ensino fundamental. O conteúdo apresenta o mito do surgimento do dia e da noite do Povo indígena Kayabi, etnia do estado do Mato Grosso. E é neste contexto explicativo que a figura do Pajé emerge como um organizador da vida Kayabi, alguém que produz intervenções em prol da coletividade a partir do uso de recursos da natureza - as cabaças de amendoim. Compreendemos os mitos como "[...] narrativas de conteúdo altamente simbólico que tratam das origens do mundo, de tempos ancestrais e diferentes do nosso, dos seres que nele habitavam e que foram os responsáveis pela criação da atual humanidade [...]" (TASSINARI, 1995, p. 464).

A proposição dos mitos indígenas como conteúdo pedagógico foi pensado por Aracy Lopes da Silva como recurso de desconstrução das chamadas "lendas", representação que na maior parte das vezes minimiza ou esvazia seus significados. Entende que é necessário: "[...] desenvolver atividades de pesquisa específica, [...] acompanhada por uma atitude de reflexão antes de tudo filosófica sobre as questões abordadas pelos mitos [...]" (LOPES DA SILVA, 1995, p. 319), talvez, um meio de aproximar os textos escritos às narrativas orais.

Foi possível avaliar que as imagens indígenas destas duas atividades localizadas em livros didáticos de História não se limitam ao currículo ancorado em datas, seja 19 ou 22 de abril, marcação que serve ao outro, ao colonialismo ou a sua reedição, a colonialidade. Conceitos que têm sido importantes para compreender a opressão de ontem e hoje. O colonialismo diz respeito às invasões europeias em territórios e mentes, denunciadas nas escritas dos subalternizados que apontam, dentre outros aspectos, a associação criminosa entre os "descobridores" e o cristianismo:

[...] a hipocrisia é recente; que nem Cortez, ao descobrir o México do alto do grande téocalli, nem Pizarro, diante de Cuzco (e muito menos Marco Polo, diante de Cambaluc), se proclamam os mandatários de uma ordem superior; que matam; que saqueiam; [...]; que, neste domínio, o grande responsável é o pedantismo cristão, por ter enunciado equações desonestas: cristianismo = civilização; paganismo = selvageria, de que só se podiam deduzir abomináveis 
consequências colonialistas e racistas, cujas vítimas haviam de ser os Índios, os Amarelos, os Negros (CÉSAIRE, 1978, p. 15).

Por outro lado, os danos e violações produzidas nos territórios e nas mentes ameríndias e africanas não cessaram com a exploração desencadeada a partir do século XVI. Os resquícios da violência repercutem na atualidade moderna através da colonialidade, termo que: "[...] nomeia a lógica subjacente da fundação e do desdobramento da civilização ocidental desde o Renascimento até hoje, da qual colonialismos históricos

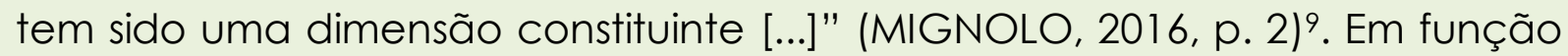
deste contexto, interpretamos que as reações dos grupos subalternos eclodem por toda a parte. A Pedagogia do Oprimido e da Oprimida proposta por Paulo Freire mobiliza esforços na busca por humanização e generosidade. Inspira releituras em diferentes contextos e nesta direção chega à instituição escolar tensionando materiais didáticos e se constituindo como relevante dispositivo de interculturalidade crítica (WALSH, 2009).

Entendo que esta possibilidade só foi possível em função das problematizações sobre o livro didático (ECO; BONAZZI, 1980; NOSELLA, 1979) e que mais tarde repercutiu na política pública expressa no Programa Nacional do Livro Didático (PNLD) que exigiu, dentre outros aspectos, a revisão das culturas dos Povos Indígenas nestes materiais:

\begin{abstract}
São os seguintes os critérios de qualificação: quanto à construção de uma sociedade cidadã, espera-se que o livro didático: [...]. 3) promova positivamente a imagem de afrodescendentes e descendentes das etnias indígenas brasileiras, considerando sua participação em diferentes trabalhos e profissões e espaços de poder; 4) promova positivamente a cultura afrobrasileira e dos povos indígenas brasileiros, dando visibilidade aos seus valores, tradições, organizações e saberes sóciocientíficos; [...] (BRASIL, 2008, p. 32).
\end{abstract}

Neste mesmo ano foi publicada a Lei 11.645/2008 que tornou obrigatório o estudo da temática indígena no currículo escolar cuja

\footnotetext{
9 Essa citação é de um artigo produzido por Walter Mignolo, cujo título é: Colonialidade: o lado mais escuro da modernidade. Um texto que faz pensar, mas uma anotação precisa ser feita: o autor é branco e talvez por isso não tenha se dado conta que em processos de revisão cultural a linguagem também precisa ser reexaminada. O termo "escuro" é inadequado e evidencia que o percurso de libertação da opressão é longo.
} 
concepção procura levar em conta as perspectivas indígenas. Diante desta normativa e das exigências do PNLD, o mercado editorial liberal teve que atender o estabelecido, condição para assegurar a aprovação, venda e comercialização de seus livros didáticos junto ao poder público.

Esta evidência, nos leva a pensar que talvez, estejamos assistindo a uma releitura da Pedagogia do Oprimido (FREIRE, 1987) ou a uma movimentação epistêmica, de reexistência no dizer de Adolfo Albán (2008), citado por Walsh (2009, p. 22): "[...] Um projeto que aponta à reexistência e à própria vida, para um imaginário "outro" e uma agência "outra" de comvivência - de viver "com" - e de sociedade". Ressignificações que repercutem na escola e em seus materiais didáticos, produzidos a partir das visões e escritos indígenas.

Quem, melhor que os oprimidos, se encontrará preparado para entender o significado terrivel de uma sociedade opressora? Quem sentirá, melhor que eles, os efeitos da opressão? Quem, mais que eles, para ir compreendendo a necessidade da libertação? Libertação a que não chegarão pelo acaso, mas pela práxis de sua busca; pelo conhecimento e reconhecimento da necessidade de lutar por ela [...] (FREIRE, 1987, p. 20).

Diante de um cenário em que a opressão reedita permanentemente mecanismos de dominação dos mundos no contexto da modernidade globalizada, os escritos freireanos inspirados na experiência vivenciada na Guiné Bissau apresentam elementos que permitem refletir sobre a questão. Refiro-me ao texto resultante do trabalho realizado entre 1976 e 1977, no campo da alfabetização de adultos que permitem compreender a necessidade de rever, problematizar e desconstruir currículos monocultuais e hegemônicos:

Neste sentido, a reformulação dos programas de Geografia, de História e de língua portuguesa, ao lado da substituição dos textos de leitura, carregados de ideologia colonialista, era um imperativo. Fazia-se necessário que os estudantes guineenses estudassem, prioritariamente, sua geografia e não a de Portugal, que estudassem seus braços de mar, seu clima e não o Rio Tejo. Era preciso que os estudantes guineenses estudassem, prioritariamente, sua história, a história da resistência de seu povo ao invasor, a da luta por sua libertação que Ihe devolveu o direito de fazer sua história, e não a 
história dos reis de Portugal e das intrigas da Corte [...] (FREIRE, 1978, p. 20).

Esta leitura permite avaliar que a Lei $11.645 / 2008$ e o Parecer 14/2015 para além de uma perspectiva legalista, pode significar uma oportunidade de tensionar o currículo escolar. Neste sentido, poderá ser possível interrogar as lições coloniais que têm produzido como projeto, imagens indígenas empobrecidas e descaracterizadas, distantes dos exuberantes patrimônios culturais, linguísticos e territoriais que as etnias representam.

Particularmente, os textos veiculados por livros didáticos com elementos críticos contribuem para trincar o currículo monocultural tendo em vista seu alcance no contexto escolar. As ilustrações apresentadas permitem compreender que a Lei 11.645/2008 e o Parecer 14/2015, constituem uma aposta de tensionamento da colonialidade:

Considerando que o Currículo constitui uma arena de luta na definição do que deve ser ensinado e aprendido, inferimos que a Lei $11.645 / 2008$ poderá ter uma chance desde que se construa mecanismos de acompanhamento e controle social, dentre outras junto ao Ministério Público, assegurando o efetivo processo de implantação junto aos sistemas de educação, bem como o investimento em processos continuados de formação docente condições fundamentais para que esta Lei alcance seus objetivos: considerar como conteúdo de aprendizagem as lições das diferenças expressas na história e na cultura afro-brasileira e indígena (NEVES, 2013, p. 8).

Esta legislação interpela o sistema educacional brasileiro a buscar diálogos com os Povos Indígenas. Neste contexto é possível levantar conhecimentos sobre o tema Pajé como interessante pauta curricular, inclusive instigar a presença destes sabedores no espaço escolar, conforme orienta O Parecer 14: "[...] lideranças indígenas (pajés, xamãs, sábios, intelectuais em geral) nas instituições de Educação Básica como formadores, palestrantes e conferencistas, dentre outras formas de reconhecimento de saberes e conhecimentos indígenas (BRASIL, 2015, p. 7, grifo nosso).

Estratégias pedagógicas que podem aos poucos mudar a feição da escola, instituindo o Currículo Intercultural com impactos nos cadernos, livros didáticos e obras literárias. Uma possível fagulha da Interculturalidade 
crítica? Como já tínhamos discutido anteriormente, este conceito decolonial vai além do inocente encontro entre as culturas, uma vez que é necessário questionar: "[...] as condições em que esse diálogo está ocorrendo e quais são os eventos históricos que não permitiram o diálogo até então [...], é necessário questionar as regras do jogo, e não somente inserir novos jogadores [...]" (GARCIA; NEVES, 2016, p. 11).

\section{CONSIDERAÇÕES FINAIS}

A finalidade principal deste trabalho foi analisar como a temática, Pajés Indígenas tem se presentificado na sala de aula e se essas práticas correspondem às exigências da Lei 11.645/2008 e do Parecer 14/2015, traduzida na questão que orientou o presente estudo. Trata-se de um recorte do Projeto de Pesquisa, em andamento, "Investigações freireanas e decoloniais: o estudo da História e Culturas Indígenas na perspectiva da Lei 1 1.645/2008 na Amazônia". É um estudo de caráter qualitativo que adotou a metodologia da Pesquisa Ação pedagógica, tendo como principal fonte de dados, a pesquisa documental.

Foi possível observar que apesar das diversas formas de anulação, demonização e invisibilidade, o Pajé enquanto autoridade indígena persiste nas práticas sociais de suas comunidades e neste caso específico, entre os Pataxó, Munduruku e Kamayurá. Dedicam-se aos processos de cura, defesa dos territórios, aconselhamento e mediações espirituais referentes as subjetividades ancestrais.

Em relação ao ambiente escolar não indígena, observamos por meio dos cadernos escolares que há veiculação de imagens do Pajé. Entretanto como um arremedo do tema, não correspondendo às realidades das etnias. Esse jeito de trabalhar a questão indígena de algumas escolas brasileiras limita-se ainda às ações pontuais em uma data previamente estipulada por ocasião da invasão europeia. Atividades desta natureza tem sido alvo de criticas por representar um indígena que não existe mais, inclusive porque o contexto Tupinambá tal qual descrito pelos cronistas viajantes, correspondente aquele período também não existe. 
No entanto, há uma luz no fim do túnel, nos referimos a presença de pajés "de verdade" nos livros didáticos analisados. Materiais que sugerem mudanças em curso, o que permite inferir que é possível trabalhar as culturas indígenas na escola como uma iniciativa decolonial que pode fortalecer a concepção de currículo intercultural com a inserção de conhecimentos importantes sobre as etnias brasileiras.

Inferimos que a publicação da Lei $11.645 / 2008$ provocou uma ampliação de estudos sobre a história e as culturas indígenas. No que diz respeito às publicações, avaliamos que esta normativa tem provocado a inserção de elementos importantes sobre o modo de vida indígena e suas contribuições no livro didático brasileiro.

Avaliamos que estudar o papel dos Pajés Indígenas no ambiente escolar pode significar uma efetiva contribuição da educação problematizadora de Paulo Freire. Uma possibilidade de assegurar consistência pedagógica rumo à elaboração de aprendizagens culturais efetivas.

Nenhuma palavra a menos representa o sentimento pela escolha do termo Pajé como contribuição à temática indígena. Um conteúdo que aliado a um conjunto de metodologias pedagógicas pode possivelmente ocupar narrativas de sustentação do Currículo Intercultural com impactos nos cadernos e livros escolares a favor dos Povos Indígenas, suas culturas e subjetividades.

\section{REFERÊNCIAS}

ANDRÉ, M.; LUDKE, M. A pesquisa em educação: abordagens qualitativas. São Paulo: EPU, 1986.

APPLE, M. W. Trabalho docente e textos: economia política das relações de classes e de gênero em educação. Porto Alegre: Artes Médicas, 1995.

ALVARES, A.; CESAR, J. P.; NICOLETI, L. Vem voar interdisciplinar. Ciências, Geografia e História. $4^{\circ}$ ano - ensino fundamental. São Paulo: Scipione, 2017.

BOTELHO, J. B.; COSTA, H. L. da. Pajé: reconstrução e sobrevivência. História, Ciências, Saúde - Manguinhos, Rio de Janeiro, v. 13, n. 4, p. 927-56, 2006. 
BONFIM, A. B. Retomando a vida: o caso de deslocamentos de uma família Pataxó. Monografia (Graduação). Formação Intercultural para Educadores Indígenas (FIEI). UFMG, Belo Horizonte, 2017.

BRASIL. Programa Nacional do Livro Didático - PNLD 2008. Edital de Convocação para Inscrição no Processo de Avaliação e seleção de obras didáticas [...]. Brasília: MEC/FNDE/SEB, 2008.

BRASIL. Lei nº $11.645 / 2008$. Inclusão no currículo oficial da rede de ensino a obrigatoriedade da temática - História e Cultura Afro-Brasileira e Indígena II Brasília, 2008. Disponível em: http://www.planalto.gov.br. Acesso em: 13 jul. 2009.

BRASIL. Parecer CNE/CEB N 14/2015. Diretrizes Operacionais para a implementação da história e das culturas dos povos indígenas na Educação Básica, em decorrência da Lei n $11.645 / 2008$. Disponível em: http://portal.mec.gov.br/index.php?. Acesso em: 22 abr. 2016.

CAMPOS NEVES, S. A Domesticação do Turismo: estratégias Pataxó na relação com agentes e agências de Turismo em Coroa Vermelha. Revista de Turismo y Patrimonio Cultural, vol. 13, n. 3, p. 567-580, 2015.

CAINELLI, M. O que se ensina e o que se aprende em História. In: OLIVEIRA, M. M. D. de (Coord.). História: ensino fundamental. Brasília: MEC, 2010.

CASTELLS, M. O poder da identidade. 5 ed. São Paulo: Paz e Terra, 1996.

CAVALHEIRO, R. M.; COSTA, F. L. A temática indígena no livro didático. 2007. Disponível em:

www.diaadiaeducacao.pr.gov.br/portals/pde/arquivos/730-4.pdf Acesso em 17 dez. 2009.

CÉSAIRE, A. Discurso sobre a colonização. Lisboa, Livraria Sá da Costa Editora, 1978.

CHARLIER, A. M. Ápis história, $5^{\circ}$ ano: ensino fundamental, anos iniciais. 2. ed. São Paulo: Ática, 2017.

CELLARD, A. A pesquisa qualitativa: enfoques epistemológicos e metodológicos. Petrópolis, RJ: Vozes, 2008.

DICIONÁRIO MICHAELIS. Pajé. Disponível em: $\mathrm{http} / / /$ michaelis.uol.com.br/busca? $r=0 \& \mathrm{f}=0 \& \mathrm{t}=0$ \&palavra=paj\%C3\%A9 Acesso em: 22 dez. 2019. 
ECO, U.; BONAZZI, M. Mentiras que parecem verdades. $5^{a}$ ed. São Paulo: Summus, 1980.

FANON, F. Os Condenados da Terra. Rio de Janeiro: Civilização Brasileira, 1968.

FRANCO, M. A. S. Práticas colaborativas na escola: as possibilidades da pesquisa-ação pedagógica. In: XVI ENDIPE - Encontro Nacional de Didática e Práticas de Ensino, 2012, São Paulo. Anais [...]. Campinas: Universidade Estadual de Campinas, 2012.

FIALHO, R. N. Para além do 19 de abril: o que os cadernos escolares revelam sobre a história e culturas indígenas? Orientadora: Josélia Gomes Neves. 2018. 67f. Trabalho de Conclusão de Curso. (Graduação em Pedagogia) Universidade Federal de Rondônia. Campus Urupá de Ji-Paraná. Ji-Paraná RO, 2018.

FREIRE, P. Cartas à Guiné-Bissau: registros de uma experiência em. Processo. 2. ed. Rio de Janeiro, Paz e Terra, 1978.

FREIRE, P. Pedagogia do oprimido. Rio de Janeiro: Paz e Terra, 1987.

FREIRE, P. Pedagogia da esperança: um reencontro com a Pedagogia do Oprimido. 17. ed. Rio de Janeiro: Paz e Terra, 1997.

FREIRE, P. Pedagogia da Autonomia: saberes necessários à prática educativa. São Paulo: Paz e Terra, 2002.

GARCIA, G. R. B.; NEVES, J. G. A interculturalidade na perspectiva de Catherine Walsh e Fidel Tubino. Revista Pedagogia, v. 3, n. 5, 1- 11, 2016.

GIL, A. C. Métodos e técnicas de pesquisa social. 6. ed. São Paulo: Atlas, 2008.

GOBBI, I. A temática indígena e a diversidade cultural nos livros didáticos de história: uma análise dos livros recomendados pelo Programa Nacional do Livro Didático. Orientador: Prof. Dr. Igor José de Renó Machado. 2007. 116 f. Dissertação (Mestrado em Ciências Sociais). Universidade Federal de São Carlos. São Carlos: UFSCar, 2007.

GRUPIONI, L. D. B. Livros Didáticos e fontes de informações sobre as sociedades indígenas no Brasil. In: LOPES DA SILVA, A.; GRUPIONI, L. D. B. (orgs.). A temática indígena na escola: novos subsídios para professores de $1^{\circ}$ e $2^{\circ}$ graus. Brasília/MEC, 1995.

JUNQUEIRA, C. Pajés e feiticeiros. Estudos Avançados, v. 18, n. 52, p. 289-302, 2004. 
LOPES DA SILVA, A.; GRUPIONI, L. D. (orgs). A Temática Indígena na Escola: novos subsídios para professores de $1^{\circ}$ e $2^{\circ}$ graus. 2. ed. São Paulo: Global; Brasília: MEC: MARI: UNESCO, 1995.

LOPES DA SILVA, A. Mito, razão, história e sociedade: inter-relações nos universos sócio-culturais indígenas. In: LOPES DA SILVA, A.; GRUPIONI, L. D. B. (orgs.). A temática indígena na escola: novos subsídios para professores de $1^{\circ}$ e $2^{\circ}$ graus. Brasília/MEC, 1995.

LUDKE, M.; ANDRÉ, M. E. D. A. de. Pesquisa em educação: abordagens qualitativas. São Paulo: Epu, 1986.

MIGNOT, A. C. V. Vitrine de Guardados: exposições de escritas ordinárias como estratégia de preservação da memória escolar. Resgate, n 14, p. 3546, 2005. Disponível em:

https://periodicos.sbu.unicamp.br/ojs/index.php/resgate/article/view/864562 8. Acesso em: 06 jan. 2019.

MIGNOLO, W. D. Colonialidade: o lado mais escuro da modernidade.

Revista Brasileira de Ciências Sociais, v. 32, n. 94, p. 1-18, 2017.

MINAYO, M. C. S. (org.). Pesquisa Social: Teoria, método e criatividade. 22. ed. Petrópolis: Vozes, 2002.

NEVES, J. G. Cultura escrita em contexto Indígena. Orientadora: Maria Rosa Rodrigues Martins de Camargos. 2009. 369f. Tese (Doutorado em Educação Escolar) Universidade Estadual Paulista, Campus de Araraquara. AraraquaraSP, 2009.

NEVES, J. G. Por uma Amazônia mais intercultural: a inserção da temática indígena no currículo pós Lei $11.645 / 2008$ por meio do uso do atual livro didático. Reunião Científica ANPEd Norte. Anais, Belém, PA, 2016. p. 28392831.

NEVES, J. G. Currículo Intercultural: processo de aplicação da Lei 11.645 /2008 nas escolas públicas da Amazônia. Revista Partes: SP. 2013. Disponível em: http://www.partes.com.br/2013/05/15/curriculo-intercultural/. Acesso em: 15 jul. de 2016.

NEVES, J. G. História e culturas indígenas na perspectiva da Lei 1 1.645/2008: o que evidenciam os cadernos escolares da alfabetização?

Anais VIII SEMPP \& I SINTEC. UNIR Portal de Eventos. 2017.

NOSELLA, M. de L. C. D. As belas mentiras: a ideologia subjacente aos textos didáticos. São Paulo: Editora Moraes. 1979. 
PRINTS, R. B. Presença indígena nos livros didáticos de Geografia. Revista Brasileira de Educação em Geografia, Campinas, v. 4, n. 8, p. 195-220, 2014.

RIBEIRO, D. O Povo Brasileiro: a formação e o sentido do Brasil. São Paulo: Companhia das letras, 1995.

RIBEIRO, B. G. A contribuição dos Povos Indígenas a cultura brasileira. In: LOPES DA SILVA, A.; GRUPIONI, L. D. B. (orgs.). A temática indígena na escola: novos subsídios para professores de $1^{\circ}$ e $2^{\circ}$ graus. Brasília/MEC, 1995.

RIBEIRO, B. G. O índio na cultura brasileira. Rio de Janeiro: Fundação Darcy Ribeiro, 2013.

SANTOS, M. L. dos. Conhecimentos tradicionais indígenas: a biopirataria no Brasil frente ao processo de globalização. Orientadora: $\mathrm{Dr}^{\mathrm{a}}$. Raquel Fabiana Lopes Sparemberger. 2008. 138f. Dissertação (Mestrado em Direito). Universidade de Caxias do Sul, Caxias do Sul-RS, 2008.

SCOPEL, D.; DIAS-SCOPEL, R. P.; LANGDON, E. J. Intermedicalidade e protagonismo: a atuação dos agentes indígenas de saúde Munduruku da Terra Indígena Kwatá-Laranjal, Amazonas, Brasil. Cad. Saúde Pública, Rio de Janeiro, v. 31, n. 12, p. 2559-2568, 2015.

SILVA, A. E. C. da; SOUSA, J. R. G. de. O mito e o rito na espiritualidade indígena: uma visão a partir dos Potiguara e Tabajara da Paraíba.

Diversidade Religiosa, v. 7, n. 1, p. 202-215, 2017.

TASSINARI, A. M. I. Sociedades indígenas: introdução ao tema da diversidade cultural. In: LOPES DA SILVA, A.; GRUPIONI, L. D. B. (orgs.). A temática indígena na escola: novos subsídios para professores de $1^{\circ}$ e $2^{\circ}$ graus. Brasília/MEC, 1995.

TELLES, N. A imagem do índio no livro didático: equivocada, enganadora. In: SILVA, A. L. da (org.). A questão indígena na sala de aula: subsídios para professores de $1^{\circ}$ e $2^{\circ}$ graus. São Paulo: Brasiliense, 1987.

WALSH, C. Interculturalidade crítica e pedagogia decolonial: in-surgir, reexistir e re-viver. In: CANDAU, V. M. (Org.). Educação intercultural na América Latina: entre concepções, tensões e propostas. Rio de Janeiro: 7 Letras, 2009.

Recebido em: 20 de maio de 2020 Aprovado em: 16 de setembro de 2020 Publicado em: 09 de novembro de 2020 